\title{
The Effect of Financial Knowledge, Financial Behavior and Financial Inclusion on Financial Well-being
}

\author{
Gita Selvia ${ }^{1}$, Dewi Rahmayanti ${ }^{2}$, Chairil Afandy ${ }^{3}$, Intan Zoraya ${ }^{4}$ \\ Department of Management, Faculty of Economics and Business-University of Bengkulu $u^{1,2,3,4}$ \\ \{gitaselvia@gmail.com¹,dewioyon@gmail.com², chai050379z@gmail.com³
}

\begin{abstract}
This study examines the effect of financial knowledge, financial behavior, and financial inclusion on financial well-being. The sampling method used in this study was purposive sampling with a total sample size of 509 . We collected data using an online questionnaire distributed via social media in Sumatra, Indonesia. Data were examined using the Partial Least Square (PLS) technique. The results showed that financial knowledge, financial behavior, and financial inclusion had a positive effect on financial well-being. We also found that financial behavior and financial inclusion mediate the influence of financial knowledge on financial well-being.
\end{abstract}

Keywords: Financial Knowledge; Financial Behavior; Financial Inclusion; Financial Well- Being

\section{Introduction}

Well-being is everyone's dream. Bakar [1] explained that well-being is a positive physical, social, and mental state. Kapoor [2] demonstrated that everyone has a different view of their level of well-being; some people feel that they can live well-being by having a lot of money. Still, some think that their well-being lies in happiness even though they only have less money. Joo [3] explains that well-being is closely related to physical and spiritual happiness or satisfaction.

There are five critical elements of well-being, according to Rath [4] that financial wellbeing is one of the five critical aspects besides community, physical, career, and social. Financial well-being is a condition in which a person has been able to fulfill financial obligations, has the preparation, and can make choices that he will enjoy now and in the future [5]. A person can be said to be well-being if he/she can maintain the standard of living and financial freedom he/she desires [6]. The standard of living refers to the combination of wealth, services, comfort, and goods available to someone considered necessary for their life [7].

From previous studies, there is no concrete definition of real well-being measures [8]. However, the well-being measure approach can be grouped into two groups, namely, using objective characteristics and subjective characteristics to define financial well-being. Accurate perception refers to a person's economic situation such as income, debt, savings, and financial capacity aspects such as knowledge and use of financial products and services. Meanwhile, subjective perception refers to individual satisfaction with their current and future financial 
situation [9]. In other words, a person may have a different assessment of financial well-being, for example, on one's attitude towards risk [10]. Therefore, the subjective approach is more comprehensive and can also capture non-financial problems than using an objective approach. This approach is more suitable for measuring personal phenomena such as financial wellbeing. Previous studies, such as research conducted by Shim [11] attempt to explain financial behavior that affects a person's subjective assessment of an individual's financial well-being by emphasizing socio-economic roles; such as gender, age, income, education level, and marital status [12], financial knowledge [13], and financial inclusion [14].

To understand financial behavior problems, an individual must know about managing their finances [15]. In ensuring financial well-being, someone needs to learn the basics of budgeting, credit management, asset protection, saving, and retirement [16]. The wrong mindset and money management can cause difficulties in achieving financial freedom [17]. Financial knowledge has also been discussed extensively by researchers [18], [19], [20]. There are many studies linking knowledge with financial behavior in financial well-being [21], [2]. In terms of financial behavior, it knows that financial knowledge is directly related to financial behavior but tends indirectly to financial well-being [21].

Like financial knowledge, this study also examines financial inclusion on financial wellbeing [22]. Indonesian Presidential Regulation [23] states that financial inclusion is a condition where everyone can have access to a variety of quality formal financial services in a timely, smooth and safe manner, and at affordable costs according to the needs and abilities of the community in improving well-being. Research by Demirguc-Kunt and Klapper [24] through the Global Findex survey states that the poorer a person, the lower his education. The lower the person's age, the lower their financial inclusion. Sharma [25] shows a positive relationship between economic growth and various dimensions of financial inclusion.

Therefore, financial inclusion plays an important role in building a strong foundation of a country's financial infrastructure, which will facilitate economic growth and development. The absence of financial inclusion may lead to financial blindness and the emergence of an unorganized financial sector, such as indigenous banking, which is highly exploitative. Financial inclusion can define as a means of providing banking/financial services to the public [25]. Financial inclusion is access to financial services such as savings, credit, payment facilities, pension funds, and several other products expected to help marginalized and lowincome groups improve their well-being and get out of poverty. It is because financial markets are the heart of the economy that can contribute to the financial well-being of society through products and services that are beneficial to society [26].

To overcome poverty conditions, the Indonesian government, through the Financial Services Authority, encourages increasing levels of knowledge, behavior, and financial inclusion to improve the well-being of the community [27]. Also, a person must work and have an income to meet the necessities of life and improve their financial well-being [28].

\section{Literature Review}

\subsection{Financial Well-being}

Financial situations affect human happiness. It focuses on the knowledge that individuals have, their behavior, and financial inclusion that can help a person achieve financial well- being. Financial well-being is also perceiving as a condition for a person to maintain the desired standard of living and financial freedom [6]. The standard of living 
refers to the combination of wealth, services, comfort, and goods available to someone considered necessary for their life [7]. It makes financial well-being a dream for everyone to meet their standard of living. Kempson [2] define financial well-being as the extent to which a person can comfortably fulfill all their current commitments and needs, and have the financial resilience to sustain them in the future. These deep personal preferences and aspirations give meaning and purpose to the financial decisions and daily sacrifices that people make to achieve what they previously planned.

\subsection{Financial Knowledge}

Financial knowledge is a person's ability to understand and take advantage of financial concepts [29]. Financial knowledge obtains through and experiences specifically related to financial concepts and financial products [30]. Howlett stated that someone who has good financial knowledge would be financially literate and better manage money more efficiently [31]. A person will act rationally to facilitate consumption during his life with good knowledge [2]. Financial knowledge will help someone to do financial planning so that it can use as a skill in applying their financial knowledge in short-term financial planning and longterm planning [32].

Research by Taft shows that financial knowledge has a positive influence on one's personal and business life. Financial knowledge helps reduce social and psychological stress and improve family well-being and personal financial well-being [22]. In the world of work, employees who have higher financial knowledge have higher efficiency and productivity; the results will help employees better understand the benefits offered by the organization to improve their well-being [33]. Research by Younas sees that financial knowledge has a direct positive influence on financial well-being [34]. The study also provides direction for governments and financial institutions, and economists to initiate programs to help others have better financial knowledge such as investing or spending daily necessities and saving for retirement, thus increasing one's well-being. Riitsalu and Murakas also state that knowledge has a strong relationship with financial well-being [13].

H1: Financial knowledge affects financial well being.

Some studies have looked at the relationship between financial knowledge and behavior. For example, knowledge of financial concepts such as inflation or compound interest correlates with better financial decisions regarding financial planning and purchasing of financial products, as in Lusardi and Mitchell [35]. Other studies have investigated the relationship between financial literacy and retirement savings [36], general savings and borrowing [37], and excess debt [38]. However, studies show the effectiveness of knowledgebased interventions that can change behavior or better combine knowledge and behavior, which have a little generalizing effect [39]. It is not entirely clear which way causality is going [40]. Hilgert [40] and Potrich [41] argue that an individual who has good financial knowledge will behave fairly and responsibly. It is also in line with Tang and Baker's research, which shows the positive influence between financial knowledge and financial behavior [15]. An individual who has financial knowledge about financial markets must make significant decisions [37].

H2: Financial knowledge affects financial behavior.

Knowledge acquired by the public can reduce information asymmetry because customers are well aware of the various financial products on the market [42]. Financial knowledge use to measure individual self-assessment ratings of financial matters related to personal financial management, setting financial goals, financial planning, bank accounts, bank products or 
services, and others [43]. Then Lusardi and Mitchell [44] also said that insufficient financial knowledge could result in lower levels of financial planning, lower levels of asset accumulation, and higher levels of use of alternative financial services. Financial knowledge is an understanding of financial concepts, so this knowledge will prevent individuals from using non-standard financial services, such as financial services offered by moneylenders who tend to harm society with uncontrollable interest [45]. Financial knowledge facilitates the decisionmaking process, which improves people's savings rates and creditworthiness by empowering their economies and communities [46]. Therefore, people need financial knowledge to empower themselves to make decisions and make strategic financial choices about the use of financial products and services [47]. Also, financial knowledge can help people to be able to evaluate various financial products and services to make the right decisions to obtain maximum utility [48]. Financial knowledge can help a person understand financial goals, such as saving or using other financial instruments [49].

H3: Financial knowledge affects financial inclusion

\subsection{Financial Behavior}

Financial behavior is the attitude and actions of an individual to do something related to their finances [2]. Positive financial behavior, such as well financial planning, financial management, and financial decision making, will boost one's the well-being and vice versa. If someone tends to shop for things that are not important beyond one's financial ability, it will impact decreasing one's financial well-being [50]. Joo and Grable [51] explain that financial behavior directly or indirectly relates to financial well-being. Several studies have looked at the relationship between behavior and financial well-being. Delafrooz and Paim [52] and Gutter and Copur [50] state that there is a tendency to spend money on things that are not implicitly important or live beyond the ability of someone who can decrease one's well-being. Research by Delafrooz and Paim [52], Finney [53], and Gutter and Copur [50] said that loans or risky use of credit for daily expenses could also reduce a person's financial well-being. A person's tendency to save and plan for the future is also associated with higher financial wellbeing [53]. Finney [53] and Gutter and Copur [50] also examined aspects of budgeting and found that they negatively correlate with financial well-being. In other words, people who plan or monitor their expenses have a lower level of financial well-being. When these behaviors control for regression analysis, shocks to income, income and expenditure, employment status, age, length of stay, and education level were also consistently associated with financial wellbeing [53]. Research by Bruggen [6] and Kempson [2] proves a positive effect between financial behavior and financial well-being. However, they use different operational methods for the two constructs.

H4: Financial behavior affects the financial well-being.

A qualitative study conducted by the Consumer Financial Protection Bureau [21] found that consumers and practitioners tend to mention the importance of knowing how to do something rather than merely having knowledge of specific facts as a potential influence of behavior. A person's knowledge does not automatically align behavior with behavior. Behavior allows a person to act for his success. The relationship between financial knowledge and financial well-being does not only have a direct effect but also has an indirect effect mediated by a person's financial behavior [21]. Kempson [2] also examined the indirect effect of knowledge on financial well-being. Where someone must be able to implement their knowledge into actions that will affect their financial well-being, it includes means of 
obtaining reliable financial information, processing that financial information to make sound financial decisions, and implementing financial decisions, monitoring and adaptation.

H6: Financial behavior mediates the effect of financial knowledge on financial well-being.

\subsection{Financial Inclusion}

Financial inclusion defines as the condition of a person who has full access and services from a financial institution in a timely, comfortable, informative and affordable manner with full respect for his or her dignity [54]. Research by Kim [20] found that credit and debt management programs can directly cope with events that can complicate individual financial conditions and indirectly affect one's financial well-being.People who practice positive financial inclusion more often have a higher level of financial well- being because they implement financial inclusion well to increase their finances. Research by Vlaev and Elliott [14] states that the regression results are significant for financial well-being, which is influenced by individual financial inclusion because individuals have control over their financial aspects to manage their finances well. Financial institutions can provide financial products and services to improve customers' financial well-being who use their services. There are also potential policy implications of lower unsecured debt benefits and increased savings to reduce unforeseen events. Zemtsov and Osipova [55] state that financial well-being is influencing by financial inclusion and the flow of income generated from assets. Thus, someone must have the ability to develop their assets to improve their financial well-being. From this research, it can conclude that a person needs to have financial management skills and the ability to invest and have financial resilience.

H5: Financial inclusion affects financial well-being.

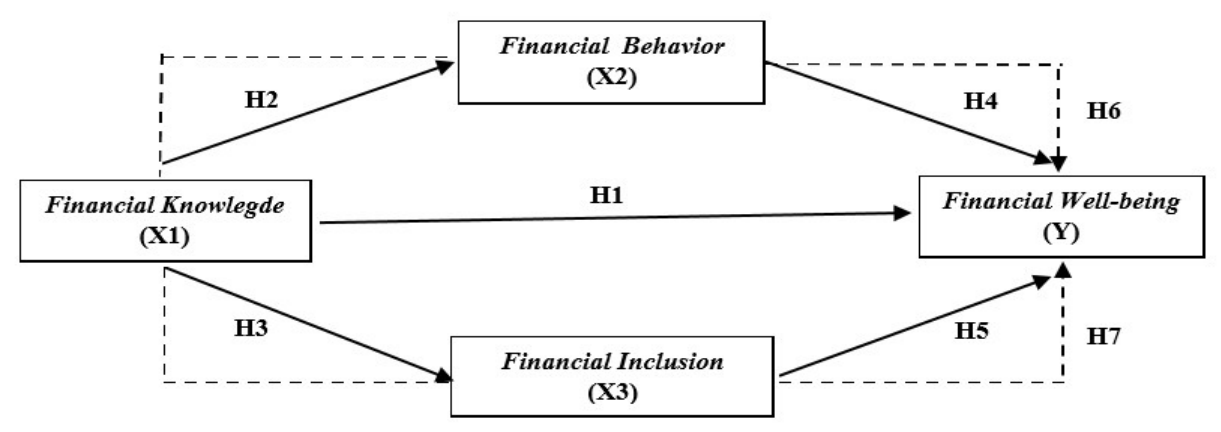

Fig. 1. Research Model

Farrell [56] explained that managing one's finances requires knowledge and understanding of finances. Hilgert [40] has conducted a study in the United States that found financial knowledge can be statistically linking to financial inclusion related to management, savings, and investment. The Financial Services Authority [27], in theory, namely financial wellbeing, states that financial knowledge can not only affect financial well-being directly, but also, there is an indirect relationship mediated by financial inclusion variables.

H7: Financial inclusion mediates the effect of financial knowledge on financial wellbeing. 


\section{Methodology}

This study is quantitative research. The research design used a survey design using an online questionnaire as a data collection tool. The sampling method used in this study was purposive sampling. The selected population sample is residents aged at least 18 years and their own personal financial organizations domiciled in Sumatra, Indonesia. The number of respondents in this study was 509 respondents.

While data analysis, such as validity test and reliability test, inner and outer model, and hypothesis testing was carried out using the SmartPLS program. The results of hypothesis testing were carried out by the bootstrapping method. The rule of thumb used for convergent validity is outer loading $>0.7$, communality $>0.5$ and Average Variance Extracted (AVE) $>$ 0.5 [57]. The results showed that the value of AVE Communality for financial knowledge 1,000 ; financial behavior was 0.502 ; financial inclusion was 0.528 , and financial wellbeing 0.536 where the value is $>0.5$ to meet the convergent validity rule of thumb.

A reliability test is carried out to determine the accuracy, consistency, and accuracy of measuring a measuring instrument[58]. Cronbach's alpha value and composite reliability value must be greater than 0.7 , although the amount of 0.6 is still acceptable [58]. The results show that the Cronbach's alpha value and composite reliability are above 0.7 , so it can be concluded that all variable constructs have met the reliability requirements.

\section{Result and Discussion}

Based on the results of the total effect that shows in Table 1, This study tested the hypothesis by comparing the value of the t-statistic that must be greater than the value of $t$ table is 1.96 to prove acceptable. The results of testing the first hypothesis indicate that the relationship between financial knowledge and financial well-being is significant $(7,411>1.96)$. It means that financial knowledge has a positive effect on financial well-being.

The second hypothesis test results show that knowledge impacts financial behavior $(3.082>1.96)$. Thus, the effect of knowledge on financial behavior is positive. The third hypothesis results show that knowledge affects financial inclusion $(5,336>1,96)$; therefore, that financial knowledge has a positive effect on financial inclusion. The results of testing the fourth hypothesis indicate that financial behavior affects financial well-being $(6,665>1.96)$. Thus, the effect of financial behavior on financial well-being is positive. The results of testing the fifth hypothesis that financial inclusion affects financial well-being (7.005>1.96). Thus, the effect of financial inclusion on financial well-being is positive.

Table 1. Total Effect

\begin{tabular}{lccccc}
\hline & $\begin{array}{c}\text { Original } \\
\text { Sample } \\
(\mathbf{O})\end{array}$ & $\begin{array}{c}\text { Sample } \\
\text { Mean } \\
(\mathbf{M})\end{array}$ & $\begin{array}{c}\text { Standard } \\
\text { Deviation } \\
(\text { STDEV) }\end{array}$ & $\begin{array}{c}\text { t Statistics } \\
(\mid \mathbf{O} / \text { STDEV } \mid)\end{array}$ & p-Values \\
\hline $\mathrm{PK} \rightarrow \mathrm{FB}$ & 0.146 & 0.148 & 0.047 & 3.082 & 0.002 \\
$\mathrm{PK} \rightarrow \mathrm{IK}$ & 0.219 & 0.221 & 0.041 & 5.336 & 0.000 \\
$\mathrm{PK} \rightarrow \mathrm{KK}$ & 0.289 & 0.291 & 0.039 & 7.411 & 0.000 \\
$\mathrm{FB} \rightarrow \mathrm{KK}$ & 0.295 & 0.296 & 0.044 & 7.005 & 0.000 \\
$\mathrm{IK} \rightarrow \mathrm{KK}$ & 0.308 & 0.314 & 0.044 & 6.665 & 0.000 \\
\hline \multicolumn{5}{c}{$\mathrm{N}=509, \alpha=0.0$}
\end{tabular}

Source: Data processing with SmartPLS (2020) 
Table 2. Spesific Inderect Effect

\begin{tabular}{lccccc}
\hline & $\begin{array}{c}\text { Original } \\
\text { Sample } \\
(\mathbf{O})\end{array}$ & $\begin{array}{c}\text { Sample } \\
\text { Mean } \\
(\mathbf{M})\end{array}$ & $\begin{array}{c}\text { Standard } \\
\text { Deviation } \\
(\text { STDEV) }\end{array}$ & $\begin{array}{c}\text { t Statistics } \\
(\mid \mathbf{O} / \text { STDEV } \mid)\end{array}$ & p-Values \\
\hline $\mathrm{PK} \rightarrow \mathrm{FB} \rightarrow \mathrm{KK}$ & 0.043 & 0.043 & 0.015 & 2.900 & 0.004 \\
$\mathrm{PK} \rightarrow \mathrm{IK} \rightarrow \mathrm{KK}$ & 0.067 & 0.069 & 0.016 & & \\
\hline
\end{tabular}

Source: Data processing with SmartPLS (2020)

PLS is a technique that can simultaneously test measurement models and structural models, but for testing the effect of mediation, we still have to follow Baron and Kenny's rules [59]. Testing the mediation effect can be done if the main effect of the independent variable's direct relationship on the dependent variable is significant [60]. The total effect describes the amount of total effect a construct receives from other constructs; the total effect is also defined as the total direct effect plus the indirect effect [61].

The results of testing the sixth hypothesis indicate a relationship between financial knowledge and financial well-being, which is mediated by financial behavior. However, the nature of the mediation is only partial (path mediation) because the t-statistic value is greater than the t-table, namely 7.441 (t-statistic $>1.96)$. So it can be interpreted that basic financial knowledge can have a direct influence on well-being even without a mediator. However, suppose the mediation effect test of financial behavior remains significant. In that case, it produces a t-statistic value that is greater than the t-table value, which is 2.900 (tstatistic $>1.96$ ) and a p-value of 0.004 (p-value $<0.05$ ). It shows that the sixth hypothesis in this study is accepted.

The results of testing the seventh hypothesis indicate a relationship between financial knowledge and financial well-being mediated by financial inclusion. However, the nature of the mediation is only partial (path mediation) because the t-statistic value is greater than the $\mathrm{t}$ table, namely 7.441 (t-statistic $>1.96$ ). So it can be interpreted that basic financial knowledge can have a direct influence on well-being even without a mediator. However, suppose the test of the mediation effect of financial inclusion remains significant. In that case, it produces a tstatistic value that is greater than the t-table value, which is 2,900 (t-statistic $>1.96$ ) and a pvalue of 0.004 ( $p$-value $<0.05$ ). It shows that the seventh hypothesis in this study is accepted.

This study proves that financial knowledge affects financial well-being. It means that the higher a person's financial knowledge can increase their financial well-being. People who have good financial knowledge can use knowledge as a basis for managing financial finances that will improve the financial well-being of people in Sumatra. This study's results support the findings of previous studies found by Joo and Grable [51]. The results of their research found that financial knowledge has a positive effect on financial well-being. The findings of Delafrooz and Paim [62] and Robb and Woodyard [37] also confirm the results of previous findings that financial behavior has a significant positive effect carried out through the National Financial Capability Study administered by the Financial Industry Regulatory Authority (FINRA). Also, Falahati [63] and Sabri and Falahati [36] are also interested in predicting financial well-being among students and individual employees. Even with different respondents and different contexts, financial knowledge has been shown to have an essential role in a person's financial well-being. The results of this study indicate that good financial knowledge will help get financial well-being. According to Bowen, financial knowledge is described as a function of understanding financial terms and concepts in everyday life [18].

This study found that financial knowledge has a positive effect on financial behavior. These results indicate that the higher a person's financial knowledge will impact the increasing 
level of that person's financial behavior. The factors causing financial knowledge's influence on financial behavior are because financial knowledge can help individuals do better financial planning, make effective decisions, and more effective financial management. This study's results support the findings of previous studies found by Hilgert and Potrich argued that an individual who has good financial knowledge would behave fairly and responsibly [40], [41]. It is also in line with research Tang and Baker [15], which shows the positive influence between financial knowledge and financial behavior. An individual who has financial knowledge regarding financial markets must make effective decisions [37]. This research supports Lusardi and Mitchell [35], which, in their research, looked at the relationship between financial knowledge and financial behavior. They found that knowledge of financial concepts such as inflation or compound interest correlated with better financial decisions regarding financial planning and purchasing financial products. Other research that parallel with this study also investigates the relationship between financial literacy and retirement savings [36], savings and general borrowing [37], and excess debt [38].

This research also shows that financial knowledge has a positive effect on financial inclusion. It is because financial knowledge can be used as a basis for thinking about what financial products are the most appropriate and can provide maximum benefits. Financial knowledge is used to measure individual self-assessment ratings of financial matters related to personal financial management, setting financial goals, financial planning, bank accounts, bank products or services [31], [43]. The effect of financial knowledge on financial inclusion is positive and significant. This study's results support the findings of Cole [64], which found that the relationship between financial knowledge has a positive and significant effect on financial inclusion. If individuals are not familiar and comfortable with financial products, they will not likely try to use it. Sound financial knowledge of financial concepts will help individuals avoid using non-standard financial services, such as moneylenders' financial services, who tend to harm society with uncontrollable interest [45].

This study also indicates that financial behavior has a positive effect on financial wellbeing. This finding explains that a higher level of financial well-being is influenced by good personal financial management and practices. This finding is consistent with previous studies conducted by Delafrooz and Paim [52]; and Zaimah [9], which stated that financial behavior is the primary determinant of financial well-being. Xiao [65] stated that individuals with better financial behavior would experience higher financial well-being. Xiao [65]; and Joo [3] state financial behavior as the main factor in determining the satisfaction of a person's financial status. It shows that good financial behavior has a positive correlation to financial well-being [11]; [66].

Meanwhile, bad financial behavior has a negative correlation with financial well-being [10]. Xiao [66] explains that positive financial behavior will improve one's financial wellbeing. Meanwhile, individuals who have a greater frequency of malicious financial behavior, such as late paying bills, have lower financial well-being [67]. Not only that, but Xiao [65] also revealed that financial behavior such as credit management, savings, and cash management is positively related to the overall well-being of the individual. This study's results are in line with the results of previous studies, meaning that the results of this study expand the empirical evidence that there is a relationship between financial behavior and financial well-being. Practically, the results of this study also contribute to the economic rate in Sumatra. It proves that positive behaviors such as well financial planning, financial management, and financial decision making will boost a person's well-being. The tendency to shop for things that are not important beyond one's financial ability will impact decreasing one's financial well-being [50]. The use of credit cards and making loans for daily expenses is 
at risk of reducing one's financial well-being [52]. The tendency to save and plan for the future is also associated with higher financial well-being [53]. This study is in line with Kempson [2], which proves a positive effect between financial behavior and financial well-being.

This research also proves that financial behavior has a positive effect on financial wellbeing. This finding explains that a higher level of financial well-being is influenced by better utilization of financial products and services. The results of this study explain that individuals with high levels of financial inclusion influence their financial well-being. Access or availability of suitable and affordable financial products and services such as bank accounts, insurance, and credit has a positive effect on financial well-being [68]. Financial inclusion can enable individuals to overcome financial instability, making it easier to carry out daily activities. Research conducted by Muir [68] shows that people with lower financial inclusion levels have worse financial well-being, among others. It is because an individual who makes fair use of financial inclusion can improve his financial well-being. Research conducted by Zemtsov and Osipova [55] states that the use of financial inclusion to generate income from owned assets affects one's financial well-being. Thus, a person must have the ability to develop their assets to improve their financial wel-being. This is also in line with the Financial Services Authority [27] that says people who use financial products and services must carry out good financial management and develop their assets to create a prosperous society.

This research reveals that financial behavior positively mediates financial knowledge on well-being. It explains that someone who has good knowledge will have effective behavior to achieve financial well-being. The Consumer Financial Protection Bureau [5], in his research, found that individuals are more concerned with knowing how to do something than just having specific knowledge for more potential behavior. It makes someone's financial knowledge not automatically make the behavior consistent with one's own. Behavior allows a person to act for his success. The relationship between knowledge and financial well-being is considered mediated by a person's behavior [5]. The research results also strengthen Kempson [2], which also examined the direct influence of financial behavior on financial well-being and the indirect effect of knowledge on financial well-being. Someone must be able to implement their knowledge into actions that will affect their financial well-being, such as processing financial information to make good financial actions to impact financial well-being.

This research also reveals that financial inclusion mediates the effect of financial knowledge on accepted financial well-being. It shows that financial inclusion can mediate the effect of financial knowledge on financial well-being. The mediating nature provided by financial inclusion is partial mediation. It means that financial knowledge can influence financial well-being even without the mediator variable. So, even though financial inclusion can be considered as a mediating variable, it can only partially mediate (partial mediation) because the variable financial knowledge can directly influence the financial inclusion variable.

The results of this study support the statement which explains that financial inclusion can still be a link between financial knowledge and financial well-being, even though it is not the main factor that can affect financial well-being. So, financial inclusion is defined as a condition where everyone can access products and quality financial services, affordable, comfortable, and satisfying. It can be concluded that knowledge refers to one's understanding of the financial products and services offered. This understanding of financial products and services will encourage financial products and services to better suit one's needs and make it easier for someone to carry out their daily activities. This finding is consistent with previous studies conducted by Hilgert [40], whose research results found financial inclusion to mediate the relationship between financial knowledge and financial well-being. Farrell [56] also 
confirm the results of previous findings that financial knowledge of financial well-being is mediated by financial inclusion. It explains that managing finances using one's financial products and services requires knowledge and understanding of finance to improve financial well-being.

\section{Conclusions}

The conclusion from this research is that financial knowledge has a significant positive effect on financial well-being, financial behavior, and financial inclusion. This study also found the influence of financial behavior and financial inclusion on financial well-being. As well as financial behavior and financial inclusion mediate the effect of financial knowledge on financial well-being.

The public should continue to improve their financial knowledge by continuing to study independently and in groups both offline (for example, by attending seminars, education, group sharing) and online (for example, by watching videos and reading websites on finance). This increasingly accessible learning must be put to fair use so that it can increase positive financial behavior, such as doing good financial planning, managing finances and making better decisions. Good financial knowledge can also be utilized in the use of more efficient and effective financial products and services following the needs of each individual to improve financial well-being.

For consultants or financial institutions as well as the government, it can take advantage of the role of financial knowledge to make users of financial products and services wiser in making decisions related to finance. So, no individual is trapped in financial products that are not profitable (for example, fake investments, making loans to moneylenders and others).

The government, consultants or financial institutions must also provide education both online and offline that is easy to understand and the process by the community to increase public interest in using financial services and legal product, according to the needs of each individual. Financial consultants or institutions can direct individuals who wish to use financial products and services that are tailored to the benefits and risks that are desired by each individual. Therefore, financial knowledge must continue to be developed, which must continue to be done for the future.

\section{References}

[1] Aisyah Abu Bakar, Mariana Mohamed Osman, Syahriah Bachok, Mansor Ibrahim, and Mohd Zin Mohamede, "Modelling Economic Wellbeing And Social Wellbeing For Sustainability: A Theoretical Concept," Procedia Environmental Sciences, vol. 28, pp. 286-296, 2015.

[2] Elaine Kempson, Andrea Finney, and Christian Popp, "Financial well-being: a conceptual model and preliminary analysis," 2017.

[3] S. Joo, "Personal financial wellness," In Handbook of consumer finance research, pp.21-33, 2008.

[4] Tom Rath, Harter K. James, and Harter Jim, Wellbeing: The five essential elements.: Simon and Schuster, 2010.

[5] Consumer Financial Protection Bureau, "Financial well-being: The goal of financial education," 2015. 
[6] E. C. Bruggen, J. Hogreve, M. Holmlund, S. Kabadayi, and M. Lofgren, "Financial Well-being: A Conceptualization and Research Agenda.," Journal of Business Research, 2017.

[7] B. C. Y. Fah, "Living Standard, Living Level and Economic Wellbeing of Older Persons: Similarity and Differences in Measuring These Concepts," Canadian Social Science, vol. 6(5), p. 145, 2010.

[8] L. Guo, E. J. Arnould, T. W. Gruen, and C. Tang, "Socializing to coproduce: pathways to consumers' financial well-being," Journal of Service Research, vol. 16(4), pp. 549563, 2013.

[9] R. Zaimah et al., "Financial well-being: Financial ratio analysis of married public sector workers in Malaysia," vol. 9(14), no. 1, 2013.

[10] J. Kim and E. T. Garman, "Financial Stress And Absenteeism: An Empirically. Derived Model," Journal of Financial Counseling Planning, vol. 14(1), p. 31, 2003.

[11] S. Shim, J. J. Xiao, B. L. Barber, and A. C. Lyons, "Pathways to life success: A conceptual model of financial well-being for young adults," Journal of Applied Developmental Psycholog, vol. 30(6), pp. 708-723, 2009.

[12] C. Larkin, B. M. Lucey, and M. Mulholland, "Risk tolerance and demographic characteristics: Preliminary Irish evidence," Financial Services Review, vol. 22(1), 2013.

[13] L. Riitsalu and R. Murakas, "Subjective financial knowledge, prudent behaviour and income: The predictors of financial well-being in Estonia," International Journal of Bank Marketing, vol. 37(4), pp. 934-950, 2019.

[14] I. Vlaev and A. Elliott, "Financial well-being components," Social Indicators Research, vol. 118(3), pp. 1103-1123, 2014.

[15] N. Tang and A. Baker, "Self-Esteem, Financial Knowledge And Financial Behavior," Journal of Economic Psychology, vol. 54, pp. 164-176, 2016.

[16] J. Dew and J. J. Xiao, "The Financial Management Behavior Scale: Development AndValidation," Journal of Financial Counseling Planning, vol. 22(1), p. 43, 2011.

[17] J. R. Kapoor, L. R. Dlabay, and R. J. Hughes, Personal Finance (Tenth ed.).: McGrawHill Irwin, 2012.

[18] C. F. Bowen, "Financial knowledge of teens and their parents," Financial counseling planning, vol. 13(2), no. 93-102, 2002.

[19] M. Courchane and P. Zorn, "Consumer literacy and credit worthiness. Proceedings,"Federal Reserve Bank of Chicago, vol. 3, 2005.

[20] J. J. Kim, "Financial knowledge and subjective and objective financial well-being", Consumer Interests Annual, vol. 47, pp. 1-3, 2001.

[21] Consumer Financial Protection Bureau, "Measuring Financial Well-Being: A guide to using the CFPB financial well-being scale," 2015.

[22] M. K. Taft, Z. Z. Hosein, S. M.T. Mehrizi, and A. Roshan, "The relation between financial literacy, financial wellbeing and financial concerns," International Journal of Business Management, vol. 8(11), p. 63, 2013.

[23] "Peraturan Presiden Republik Indonesia Nomor 82 Tahun 2016 Tentang Strategi Nasional Keuangan Inklusif," 2016.

[24] A. Demirguc-Kunt and L. Klapper, "Measuring financial inclusion: The global financial Index database: The World Bank," 2012.

[25] M. Sarma, "Index Of Financial Inclusion," 2008.

[26] A. Hannig and S. Jansen, Financial inclusion and financial stability Current policy issues., 2010. 
[27] Otoritas Jasa Keuangan, "Strategi Nasional Literasi Keuangan Indonesia (Revisit 2017)," 2017.

[28] N. G. Mankiw, E. Quah, and P. Wilson, Pengantar Ekonomi Makro. Jakarta: SalembaEmpat, 2006.

[29] OECD. (2018) Toolkit For Measuring Financial Literacy And Financial Inclusion. [Online]. www.oecd.org

[30] S. J. Huston, "Measuring financial literacy," Journal of Consumer Affairs, vol. 44(2), pp.296-316, 2010.

[31] Elizabeth Howlett, Jeremy Kees. , and Elyria Kemp, "The role of self-regulation, future orientation, and financial knowledge in long-term financial decisions," Journal of Consumer Affairs, vol. 42.2, 2008.

[32] Boris Palameta, Cam Nguyen, Taylor Shek-wai Hui, and David Gyarmati, The Link Between Financial Confidence and Financial Outcomes Among Working-Aged Canadians: Social Research and Demonstration Corporation, For the Financial Consumer Agency of Canada ed.: Social Research and Demonstration Corporation, 2016.[Online]https://financialcapability.gov.au/files/thelinkbetweenfinancialconfidence andfinancialout comes-canada-2016.pdf

[33] P. Brennan, "Personal Finance Education: What Employees Need And Want To Know,"Personal Finance Worker Productivity, vol. 2(1), pp. 68-74, 1998.

[34] Waqar Younas et al., "Impact of Self-Control, Financial Literacy and Financial Behavior on Financial Well-Being," The Journal oSocial Sciences Research, vol. 5(1), pp. 211-218, 2019.

[35] A. Lusardi and O. S. Mitchell, "The Economic Importance Of Financial Literacy: Theory And Evidence," Journal of economic literature, vol. 52(1), p. 544, 2014.

[36] J. M. Jacobs-Lawson and D. A.J. Hershey, "Influence of future time perspective, financial knowledge, and financial risk tolerance on retirement saving behaviors," Financial Service Review, vol. 14(4), p. 331, 2005.

[37] C. A. Robb and A. Woodyard, "Financial knowledge and best practice behavior", Journal of Financial Counseling Planning, vol. 22(1), 2011.

[38] J. Gathergood, "Self-Control, Financial Literacy And Consumer OverIndebtedness,"Journal of Economic Psychology, vol. 33(3), pp. 590-602, 2012.

[39] Daniel Fernandes, John G. Lynch Jr., and Richard G. Netemeyer, "Financial Literacy, Financial Education, and Downstream Financial Behaviors," Management Science, vol.60(8), pp. 1861-1883, 2014.

[40] M. A. Hilgert, J. M. Hogarth, and S. G. Beverly, "Household financial management: The connection between knowledge and behavior," Journal Fed. Res. Bull., vol. 89, p. 309,2003.

[41] A. C. G. Potrich, K. M. Vieira, and W. Mendes-Da-Silva, "Development Of A Financial Literacy Model For University Students," Management Research Review, vol. 39(3), pp.356-376, 2016.

[42] Oya Pinar Ardic, Maximilien Heimann, and Nataliya Myle, "Access to financial services and the financial inclusion agenda around the world: A cross-country analysis with anew data 2013. https://elibrary.worldbank.org/doi/abs/10.1596/1813-9450-5537

[43] Deon Harold Tustin, "An Impact Assessment Of A Prototype Financial Literacy Flagship Programme In A Rural South African Setting," African Journal of Business Management, vol. 4(9), pp. 1894 - 1902, 2010. [Online]. https://academicjournals.org/journal/AJBM/article-abstract/4692E2532393 
[44] Annamaria Lusardi and Olivia S. Mitchell, "Planning And Financial Literacy: How Do Women Fare?," American Economic Review, vol. 98(2), pp. 413-417, 2008.

[45] S. Braunstein and C. Welch, "Financial Literacy: An overview of practice," Research, and policy, vol. 88, p. 445, 2002.

[46] Ghirmai T Kefela, "Knowledge-based economy and society has become a vital commodity to countries," International NGO Journal, vol. 5 (7), pp. 160-166, 2010.

[47] OECD, "Literacy Financial and Consumer Protection: Overlooked Aspects of the Crisis", 2009.

[48] A. Lusardi, "Household Saving Behavior: The Role of Financial Literacy, Information, and Financial Education Programs," National Bureau of Economic Research, 2008.

[49] R. Holzmann and Robert Holzmann, Bringing financial literacy and education to low and middle income countries: the need to review, adjust, and extend current wisdom. Washington DC: World Bank, IZA and CES, 2010.

[50] M. Gutter and Z. Copur, "Financial Behaviors And Financial Well-Being Of College Students: Evidence From A National Survey," Journal Of Family Economic Issues, vol.32(4), pp. 699-714, 2011.

[51] S. H. Joo and J. E. Grable, "An Exploratory Framework Of The Determinants Of Financial Satisfaction," Journal Of Family Economic Issues, vol. 25(1), pp. 25-50, 2004. [52] N. Delafrooz and L. H. Paim, "Role Of Financial Stress On Relationship Between Financial Problem And Financial Wellness Among Malaysia Workers," African Journal of Business Management, vol. 7(20), pp. 1966-1972, 2013.

[53] A. Finney, "Components of financial capability: defining, measuring and predicting scores in the UK population," London,.

[54] Bank Indonesia, "Booklet Keuangan Inklusi," Departemen Pengembangan Akses Keuangan dan UMKM Bank Indonesia, Jakarta, 2014.

[55] A. Zemtsov and T. Osipova, "Financial Wellbeing as a Type of Human Wellbeing: Theoretical Review," The European Proceedings of Social Behavioural Science, vol. 7, pp. 385-392, 2016.

[56] L. Farrell, T. R. Fry, and L. Risse, "The significance of financial selfefficacy in explaining women's personal finance behaviour," Journal of Economic Psychology, vol. 54, 2016.

[57] Wynne W. Chin and Peter A. Todd, "On The Use, Usefulness, And Ease Of Use Of Structural Equation Modeling In MIS Research: A Note Of Caution," MIS Quarterly, vol. Vol. 19, No. 2, pp. 237-246, June 1995. [Online]. https://www.jstor.org/stable/249690

[58] W. Abdillah and Jogiyanto, Partial Least Square (PLS) Alternatif Structural Equation Modeling (SEM) dalam Penelitian Bisnis, 1st ed. Yogyakarta: ANDI, 2015.

[59] W. Abdillah and Jogiyanto, Partial Least Square (PLS) Alternatif Structural Equation Modeling (SEM) dalam Penelitian Bisnis, 1st ed. Yogyakarta: ANDI, 2015.

[60] R.M Baron and D.A Kenny, "The Moderator-Mediator Variable in Social Psychological Research," Journal of Personality and Social Psychology, 1986.

[61] S. Yamin and H. Kurniawan, Structural equation modeling: Belajar lebih mudah teknik analisis data kuesioner dengan lisrel-PLS. Jakarta: Salemba infotek, 2009.

[62] N. Delafrooz and L. H. Paim, "Determinants of Financial Wellness Among Malaysia Workers," African Journal of Business Management, vol. 5(24), p. 10092, 2011.

[63] L. Falahati, M. F. Sabri, and L. H. Paim, "Assessment a model of financial satisfaction predictors: Examining the mediate effect of financial behavior and financial strain," World Applied Sciences Journal, vol. 20(2), p. 190197, 2012. 
[64] S. Cole, T. Sampson, and B. Zia, "Prices or knowledge? What drives demand for financial services in emerging markets? ," The journal of finance, vol. 66(6), pp. 1933$1967,2011$.

[65] Xiao Jing Jian, Chuanyi Tang, and Soyeon Shim, "Acting for happiness: Financial behavior and life satisfaction of college students," Social indicators research, vol. 92(1), pp. 53-68, 2009.

[66] Jing Jian Xiao, Applying Behavior Theories to Financial Behavior, Handbook of Consumer Finance Research ed. New York: Springer, 2008.

[67] B. O'Neill, B. Sorhaindo, J. J. Xiao, and E. T. J. Garman, "Financially distressed consumers: Their financial practices, financial well-being, and health," Journal of Financial Counseling and Planning, vol. 16(1), 2005.

[68] K. Muir et al., "Exploring Financial Wellbeing In The Australian Context," 2017. 